\title{
SENSORY NERVE TERMINATIONS IN THE TENDONS OF THE EXTRINSIC EYE-MUSCLES OF
} THE CAT.

\author{
By G. Carl Huber, \\ Junior Professor of Anatomy and Director of the Histological Laboratory, \\ University of Michigan. \\ With Plate XII.
}

In a former communication the writer ( $\mathrm{l}$ ) drew attention to a nerve-termination in the extrinsic eye-muscles of the rabbit, which differed from the motor endings found in these muscles and which for reasons there given were described as sensory nerve-endings. It is my purpose in this short paper, to call attention to a sensory nerve-ending in the tendons of the extrinsic eye-muscles of the cat which differs in many respects from the neuro-tendinous end-organs found in the tendons of other skeletal muscles of this animal.

Golgi (2) in his communications on the nerves in tendon and on the "musculo-tendinous end-organ" states that these nerve-endings have a very wide distribution, being found in practically all tendons except those of the eye-muscles. Soon after the appearance of Golgi's research on this subject, Victor Marchi re-investigated the eye-muscles with reference to this point, and in a short paper bearing on this question asserts the presence of these tendon end-organs in the eye-muscles of a number of mammals. He states having found them in cattle ('Rind'), the pig, dog, cat, rabbit and man. Marchi's description of these nerve-endings as found in eye-muscles of cattle is in its essentials as given in the following abridged and free translation.

In the transition zone between the fleshy and tendinous portion of the eye-muscles, he observed a nerve trunk coming from the muscular portion, having at times a straight course, at 
other times a spiral course, which divided into two to four branches, each branch ending in a spindle-shaped structure, which from its reaction to the stains used could readily be distinguished from the surrounding tendon-bundles. These spindleshaped structures were surrounded by a transparent sheath. Spindles branched at either the central or peripheral end, were observed. Soon after entering the spindles, the nerve-fibers divide into two, three, or even more diverging branches, which sooner or later lose their medullary sheath and as non-medullated fibers approach the periphery of the spindles where they may end abruptly or terminate between small granules found in their superficial portion. The further division and the exact termination of the nerve-fibers he was not able to make out. In each tendon four to six endings were found. As in any one tendon not all the nerve-endings may have been stained, the number above given may be too low.

I have given thus fully Marchi's account of the nerve-ending in the tendons of the eye-musle of cattle, as in other mammals examined with reference to this point identical end-organs were found, as the following quotation which follows the above statement, will show: "Ich dehnte nach und nach meine Untersuchungen auf die Augenmuskeln anderer Thiere aus und fand bei allen die Terminalkörper in derselben Form und Grösse wieder, so dass die den verschiedenen Thierarten entnommenen Präparate gar nicht von einander zu unterscheiden waren." As in the earlier portion of his paper he mentions the cat as one of the animals which came within range of his investigation, it is permissible to assume that the nerve-endings found by him in the tendons of the eye-muscles of the cat were in shape, size and structure like the nerve-endorgan above described.

Ciaccio (4) mentions and figures the neuro-tendinous endorgans in the eye-muscles of man, but does not give special consideration to those found in the cat. My own observations were made with the methylen blue method. Through a canula inserted into one of the carotid arteries a 1 per cent. solution of methylen blue in normal salt was injected until the eye-lids 
and conjunctiva assumed a distinctly blue color. Some $30 \mathrm{~min}$ utes after the injection the eye-muscles were exposed by removing the bony wall of the orbit, and by dissecting away the fascia and adipose tissue covering the eye-muscles. As soon as the muscles and tendons were exposed they were removed and transferred to a slide moistened in normal salt, care being taken to cut the tendons as near their ocular insertion as possible and to place them on the slide with the ocular side downwards. The muscle remained on the slide until, on examination with the microscope, the nerve-endings seemed well stained. The tissue was then fixed, either in an ammonium picrate solution and mounted in ammonium picrate glycerine, or in ammonium molybdate (Bethe). Tissues fixed by the latter method were embedded, sectioned and counter-stained in alum carmine and mounted in balsam.

In preparations prepared by the former method it is possible to mount an entire eye-muscle-fleshy mass and tendonand yet have a preparation thin enough to study with high powers. I found such preparations most useful for ascertaining the general distribution of the nerves in the muscular and tendinous portion, their branching and their relation to the nerveending to be described; also the arrangement of the terminal branches of the nerves in the end-organs. Some of the details of the structure of the end-organs and the relation of the terminal nerve branches to the tissue elements were best studied in sections made as above indicated.

In preparations made after the former of the above mentioned methods, two varieties of nerve fibers (recognized by their terminations) and endings may be readily made out. Motor fibers, the endings of which are found in the middle of the fleshy mass, and rather small medullated nerve fibers, which run forward between or over the muscle fibers to the tendinous portion of the muscles, there to end in special end-organs. Similar observations have been made by Sherrington (5), as may be seen from the following statement taken from one of his papers: "I was struck with the long distance to which many of the nerve fibers in these muscles travel forward 
toward the ocular tendons of the muscles. I was more impressed with this fact because direct examination proved that the region of the distribution of the motor end-plates in these muscles is almost confined to the middle portion of the fleshy mass of the muscles. Further investigation of the course and destination of the nerve fibers at the tendon end of the muscles revealed them (both in cat and monkey) undergoing terminal sub-division and in very numerous instances passing beyond into the bundles of the tendon itself. The termination of many of the bundles of the nerves lies within the tendon; many recurve again toward the muscular fibers and end just at the junction of the muscle fiber with the tendon bundle."

The motor endings need no further consideration as they present no structural peculiarities.

The nerve fibers terminating in the tendinous portion of the eye-muscles pass forward beyond the region of the motor endings, as small bundles consisting of two, three, four or even more small medullated fibers. The small bundles have a rather direct course, passing forward between the muscle fibers, approaching the surface of the muscle some distance before the tendon is reached. Three such small bundles are represented in the accompanying figure. After leaving the fleshy portion of the muscle, these bundles pass forward into the tendon for a short distance, usually on its outer surface, although now and then in the substance of the tendon. The termination of these fibers is in end-organs situated for the most part just beyond the fleshy portion of the muscles. One or two nerve-fibers go to each end organ. Many nerve fibers pass forward beyond their point of termination for a short distance, to recurve again toward the muscular fibers before ending, as Sherrington (5) has eorrectly stated Others approach the end-organs more directly, entering them either at their distal (which seems to me the more common) or their proximal ends. As the nerve fibers approach the end-organs, the internodal segments become shorter (this Sherrington has observed); the axis cylinders do not, however, become thicker. In this respect my observations do not corroborate Sherrington's (5) if, in the following state- 
ment, he has reference also to the axis cylinders: "The nervefibers in so terminating frequently become thick . . . . with shortened internodes." The bundles of small medullated fibers, as also the single fibers, are surrounded by a distinct fibrous sheath-a sheath of Henle.

The end-organs in question (which, as may here be stated, are simple neuro-tendinous spindles) consist of a tendon fasciculus surrounded by a thin, closely fitting fibrous sheath in which oval or oblong nuclei are found. (The sheaths surrounding the tendon fasciculi are not shown in the figure; they are not clearly seen in preparations mounted in ammonium-picrate-glycerine; they are, however, readily made out in sections of tissue fixed in ammonium molybdate.) This sheath becomes indistinct at the central and peripheral end of the end-organs and seems to blend with the fibrous tissue found between the tendon fasciculi and muscle fibers. The shape of this end-organ is more that of a cylinder than a spindle, as neither the tendon facsciulus nor the space between it and the sheath, which in all parts is narrow, are perceptibly thickened in the equatorial region. As above stated, one or two medullated fibers terminate in each end-organ. They pass through the fibrous sheath as medullated fibers with short internodes, losing the medullary sheath soon after entering. The naked axis cylinders then break up into several divergent branches, which undergo repeated further division, the resultant branches bearing the character of non-medullated fibers with numerous irregular varicosities of variable size. These terminal branches become so interlaced and interwoven that in a well stained preparation it becomes very difficult to follow them. I have attempted to reproduce these endings in the accompanying figure, to which the reader is referred in lieu of a more detailed description. This plexus is spread out over the tendon fasciculus, but under the fibrous sheath surrounding it. Some of the terminal branches penetrate the tendon fasciculus for a short distance, as may be seen in cross-sections.

The nerve termination here described differs in many respects from that found in the neuro-tendinous spindles found in 
other skeletal muscles of the cat, and while there may be some similarity between the two varieties of endings, this seems not as close as the following statement of Sherrington (5) might indicate: "This terminal arborisation which the nerve-fibers finally make is, as a rule, small as compared with the end-arborisations of the ordinary Kühne-Ruffini 'spindle' or the Golgi 'tendon organ but closely resembles in numerous instances the form of arborisation of the latter."

The end-organs here described have been found in all the recti and obliqui eye-muscles of the cat, so far never in the retractor of the bulb. In my preparations they have been relatively more numerous in the superior rectus than in the other eye muscles. This may, however, be due to the fact that the nerve-fibers and endings seemed always best stained in the superior rectus. In a number of my preparations I have been able to count some 25 to 30 end-organs in one muscle. In such preparations there is nearly a continuous band of end-organs across the entire tendon, just distal to the fleshy portion of the muscle; a band in which the end-organs are quite as numerous as in the small portion of tendon reproduced in the figure.

It is of interest to note that the nerve fibers ending in these end-organs are not branches of the ophthalmic division of the trigeminus, but that the III, IV and VI nerves, although purely muscular, must be sensori-motor. This the excellent and painstaking experiments of Sherrington $(5-6)$ would seem to show conclusively.

\section{LITERATURE.}

1. Huber. A Note on Sensory Nerve-endings in the Extrinsic Eye-mascles of the Rabbit. "Atypical Motor-endings" of Retrius. Anat. An. seiger, Vol. XV, 1899.

2. Camillo Golgj. Sui nervi dei tendini, e di un nuovo organo nervoso terminale muscolo-tendineo. Memoire della R. Academia delle Sciestse di Torimo, Serie II, tomo XXXII. I have consulted-Ueber die Nerven der Sebnen des Menschen und anderer Wirbeltbiere und über ein neues nervőses musculo-tendinőses Endorgan. Untersuchungen uber den feineren Beu des centralen und peripherischen Nervensystems. Camillo Golgi, Jena, 1894. 


\section{I58 Journal of Comparative Neurology.}

3. Victor Marchi. Ueber die Terminalorgase der Nerven (Golgi's Nerwankörpercben) in den Sehnen der Augenmuskeln. v. Graefe's Archiv $f$. Ophthalmologie, Vol. XXVIII, 1882.

4. Cinccio. Sur les plaques nerveuses finales dans des vertebres. Archiv. Btal. Ne Biologie, Vol. XIV, 1891.

5. Sherrington. Further note on the sensory nerves of muscles. Procedings of the Royal Society of London, Vol. LXI, 1897.

6. Sherrington. Further note on the sensory nerves of the eye muscles. Procedings of the Roval Society of London, Vol. LXIIII, 1898-99.

\section{DESCRIPTION OF PLATE XII.}

Fig. 1. A portion of the fleshy and tendinnus portion of the superior rectus muscle of the eye of at, showing the course and termination of sensory nerve fibers as seen when stained with methylen blue, fixed in ammonium picrate and mounted and cleared in ammonium picrate-glycerine.

Cnmera lucida drawing: $\mathrm{r} \cdot 6$ in. objective, No. 2 eye-piece; reduced to one. third. 


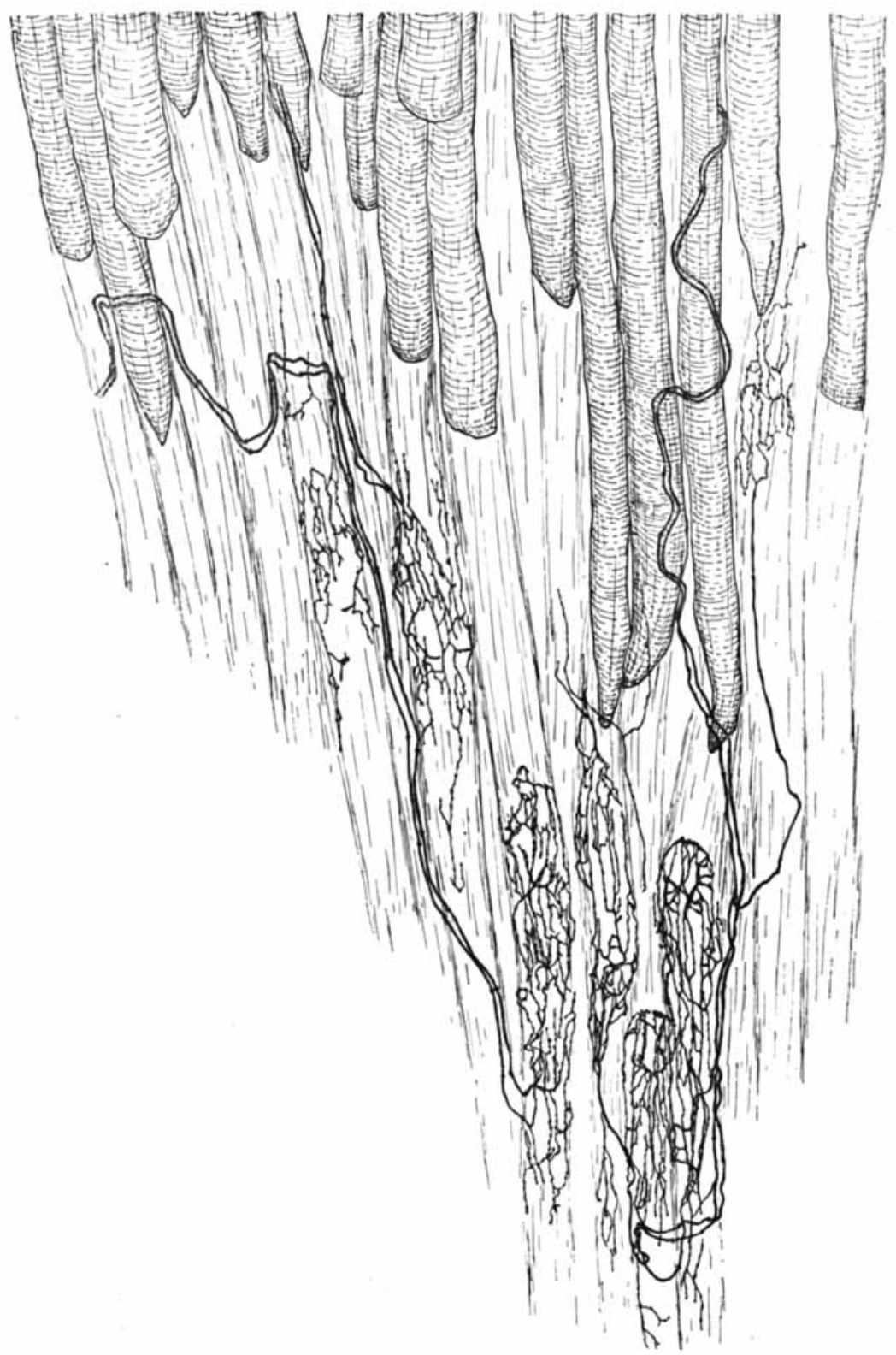

